\title{
Prevalence of Dirofilaria immitis in Dogs from Shelters in Vojvodina, Serbia
}

\author{
Doroteja Marčić', Aleksandar Potkonjak², Marina Žekić-Stošić', \\ Ljubica Spasojević Kosić ${ }^{2}$ Ivan Pušićc \& Sara Savić
}

\begin{abstract}
Background: Dirofilaria immitis is vector borne parasite of carnivores, with zoonotic potential, endemic in many parts of the world, including Europe. The aim of this study was to determine the prevalence of Dirofilaria immitis infection in dogs from shelters, especially compared to their lifestyle. Dogs living in shelters in Serbia may be at high risk of acquiring vector borne pathogens, mainly because most of them live outside in pens and backyards, in contact with vectors. Also, dogs in shelters are not always regularly treated against ectoparasites, thus, representing an easy feeding source for the vectors. The objective of this study was to determine the prevalence of Dirofilaria immitis infection in dogs from 5 shelters in South Bačka and Central Banat districts, in Autonomous Province of Vojvodina, Northern part of Serbia. Also, the objective was to compare the relation of infection with Dirofiaria immitis with age, sex, type of keeping the animals and preventive treatment in dogs. Materials, Methods \& Results: Between May 2017 and October 2019, blood samples were collected from 336 randomly selected dogs from 5 shelters in 2 districts, South Bačka and Central Banat districts, in Autonomous Province of Vojvodina, Northern part of Serbia. The epidemiological survey has been conducted with all of the dogs involved in this research. The survey was designed to collect data about sex, age, lifestyles, food type, treatment against mosquitoes with insecticides and filarioid worms with macrocyclic lactones, regular testing for Dirofilaria infections. The presence of circulating microfilariae was examined using a modified Knott's test. For the presence of circulating adult female Dirofilaria immitis antigen, serum samples were tested by commercially available enzyme-linked immunosorbent assay, which reacts to antigen of female Dirofilaria. In total, $336 \mathrm{dogs}$ were examined for the presence of Dirofilaria immitis antigen. For that dog population which came from 5 shelters, total prevalence was $25.30 \%$. Most of the positive findings were observed in a shelter where dogs lived exclusively outdoors in fenced yards in big groups and they were partly tested for heartworm infections from time to time. These dogs were not treated with macrocyclic lactones, against mosquitoes with insecticides or filarioid worms. The prevalence in this shelter was $56.36 \%$. On the contrary to that, the lowest positive findings were detected in the shelter, where dogs were allowed to move freely between outside and indoors and they were also provided with accommodation indoors. These dogs have been regularly tested for Dirofilaria infections and treated against mosquitoes with insecticides and filarioid worms with macrocyclic lactones. In this shelter the seroprevalence was $7.69 \%$. Microfilariae of Dirofilaria immitis were detected, by modified Knott's test, in all of the antigen positive dog samples; except in 2 dogs from one shelter.

Discussion: This study shows persistence of cardiopulmonary dirofiariosis in shelter dogs under different maintaining conditions. By comparing the data during the last 17 years, it can be stated that there is a constant increase of prevalence for Dirofilaria immitis in dogs in northern part of Serbia over the years. The results gained in this study are important from the veterinary point of view, but also from the Public Health point of view.
\end{abstract}

Keywords: Dirofilaria immitis, prevalence, Heartworm disease, dogs, shelter, diagnosis. 


\section{INTRODUCTION}

Cardiopulmonary dirofilariosis caused by $\mathrm{Di}$ rofilaria immitis is a vector borne disease transmitted by mosquitos, with zoonotic potential [1]. D. immitis resides in dogs and wild canids as definitive hosts [25]. Mosquito species that have been identified as vectors of dirofialrioasis in Europe are Aedes vexanus, Aedes albopictus, and Culex pipens complex [3,23]. D. immitis infections were first found in Mediterranean countries, but later the disease has spread over the Balkans and Central Europe [7-9,24,34], due to climate change, density of the vectors and travel of infected dogs [17].

Diagnostic methods available for infections with $D$. immitis are based on detection of microfilaria (modified Knott's test or filtation test), antigen (ELISA), antibodies (ELISA) or specific genes (COI by PCR) of $D$. immitis $[18,29,32]$.

The first report of cardiopulmonary dirofilariosis in dogs, in Serbia (Yugoslavia) was in 1989, during necropsy of three dogs and then in 1999 which influenced the constant diagnosis in dogs in Serbia [5,18,22,35,36]. During the last two decades dirofilariosis has spread over Serbia and multiple studies on determination and differentiation Dirofilaria spp. were conducted in hunting dogs, pet owned dogs, military dogs of Serbian army, stray dogs, dogs from shelters [26,28,40-42].
The objective of this study was to determine the prevalence of Dirofilaria immitis infection in dogs from five shelters in South Bačka and Central Banat districts, in Autonomous Province of Vojvodina, Northern part of Serbia. Also the objective was to compare the relation of infection with Dirofiaria immitis with age, sex, type of keeping the animals and preventive treatment in dogs.

\section{MATERIALS AND METHODS}

\section{Study areas, animals and sampling}

Between May 2017 and October 2019, blood samples were collected from 336 randomly selected dogs from 5 shelters in 2 districts, South Bačka and Central Banat districts, in Autonomous Province of Vojvodina, Northern part of Serbia. Samples distribution according to shelters was 94 for A, 52 for B, 65 for C, 55 for D and 70 for D. Sample size was calculated using OpenEpi software (https://www.openepi.com/ SampleSize/SSPropor.htm) [4]. Most of the dogs were medium-sized mixed breed, aged between 6 months and 15 years. In shelters B and partly D when dogs enter the shelter they are checked for D. immitis infection and if positive, they are in most cases treated. Epidemiological data about dogs from shelter are shown in Table 1.

Table 1. E Epidemiological data on origin, lifestyle, food type, treatment and age of tested dogs from 5 shelters located in South Backa and Central Banat districts in Autonomous Province of Vojvodina, Serbia

\begin{tabular}{|c|c|c|c|c|c|c|c|c|c|}
\hline \multirow{2}{*}{ Shelter } & \multirow{2}{*}{$\mathrm{N}^{\circ}$} & \multirow{2}{*}{ Dog's lifestyle } & \multirow{2}{*}{ Food type } & \multirow{2}{*}{ Treatment ${ }^{1}$} & \multirow{2}{*}{ Regular testing ${ }^{2}$} & \multicolumn{4}{|c|}{ Age } \\
\hline & & & & & & $\leq 2 \mathrm{y}$ & $2-5 y$ & $5-8 y$ & $>8 y$ \\
\hline A & 94 & In pens & Commercially produced dog food & No & No & 59 & 32 & 3 & 0 \\
\hline $\mathrm{B}$ & 52 & Indoor and outdoor & Commercially produced dog food & Yes & Yes & 21 & 12 & 8 & 11 \\
\hline $\mathrm{C}$ & 65 & Outdoor & Commercially produced dog food & No & No & 40 & 24 & 1 & 0 \\
\hline $\mathrm{D}$ & 55 & Outdoor & Commercially produced dog food & No & Partly & 34 & 16 & 2 & 3 \\
\hline $\mathrm{E}$ & 70 & Outdoor & $\begin{array}{l}\text { Commercially produced dog food, } \\
\text { bread and slaughterhouse leftovers }\end{array}$ & No & No & 51 & 19 & 0 & 0 \\
\hline
\end{tabular}

1Treatment against mosquitoes with insecticides and filarioid worms with macrocyclic lactone. ${ }^{2}$ Regular testing for Dirofilaria immitis infections.

With the consent of persons responsible for managing the shelters, a $4 \mathrm{~mL}$ blood sample was withdrawn from the cephalic vein of each dog using 2 labelled tubes, one without anticoagulants and the other with Heparin. After centrifugation, the serum samples were stored at $-20^{\circ} \mathrm{C}$ until further processing.

\section{Detection of microfilariae}

The presence of circulating microfilariae was examined using a modified Knott's test. The test was performed according to Bazzochi et al. [2]. The differentiation of microfilariae was done based on morphological characteristics of two Dirofilaria species microfilariae - the shape of cephalic and caudal ends of D. immitis and D. repens [10].

\section{Detection of adult female D. immitis antigen}

Serum samples were tested for the presence of circulating adult female $D$. immitis antigen by commercially available enzyme-linked immunosorbent assay 
VetLine Dirofilaria Antigen ELISA ${ }^{1}$ in accordance with the manufacturer's instructions.

The point prevalence was calculated within the cross-sectional design of epidemiological study.

\section{Statistical analysis}

All data were analyzed using statistical program Past $4^{2}$. The chi-square test and Fisher's test were used to estimate statistical differences between groups. The level of statistical significance was set at $P<0.05$.

\section{RESULTS}

For population of dogs from 5 shelters from the territory of South Bačka and Central Banat districts total D. immitis antigen prevalence was $25.30 \%$ $(85 / 336)$ found by ELISA method. The highest number of positive findings was observed in shelter D, where 31 were positive out of 55 tested blood sera of dogs $(56.36 \%)$. Shelter C identified 27 antigen reactive blood serum samples from dogs from 65 $(41.54 \%)$ examined. In shelter E, a total of 70 blood sera of dogs were examined, of which 12 gave a positive result, respectively a prevalence for $D$. immitis antigen of $17.14 \%$ was recorded. A prevalence for $D$. immitis antigen of $11.70 \%$ was obtained in shelter A, and a total of 94 samples were examined, of which 11 gave a positive finding. The lowest prevalence for D. immitis antigen was recorded in shelter B $7.69 \%$ where a total of 52 blood sera of dogs were tested and a positive result was obtained in 4 samples.
Microfilariae of $D$. immitis were detected, by modified Knott's test, in all of the antigen positive dog samples; except in 2 dogs from shelter B. The results of prevalence of D.immitis in 5 shelters are shown with Figure 1.

The results were also analysed by the age and sex (male/female) of the dogs and the data are shown in Table 2. There was no significant difference between males and females in any of the shelters. In all of the shelters there was a significant diference between the prevalence for D. immitis in dogs under 2 years of age, compared to all the other age groups.

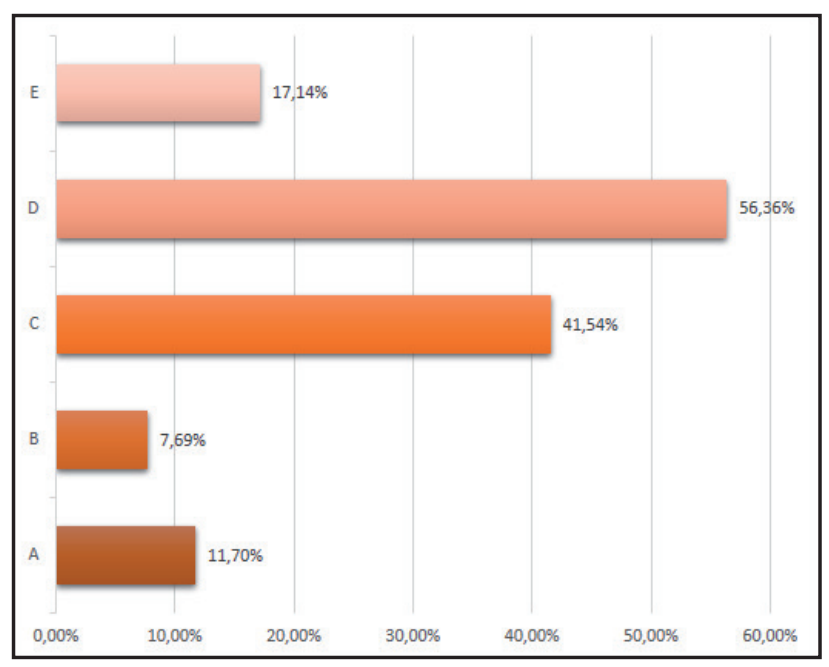

Figure 1. Total prevalence of Dirofilaria immitis in 336 randomly selected dogs from 5 shelters located in South Bačka and Central Banat districts, Autonomous Province of Vojvodina in Northern part of Serbia, from May 2017 to October 2019.

Table 2. Distribution of Dirofilaria immitis antigen positive dogs among different shelters (A-E) and according to the age and sex of dogs.

\begin{tabular}{|c|c|c|c|c|c|c|c|c|}
\hline \multirow{2}{*}{ Statistical significance } & \multicolumn{4}{|c|}{ age } & \multirow{2}{*}{$\begin{array}{c}\text { Statistical } \\
\text { significance }\end{array}$} & \multicolumn{2}{|c|}{ Sex } & \multirow{2}{*}{$\begin{array}{l}\text { Statistical } \\
\text { significance }\end{array}$} \\
\hline & $\leq 2$ god. & $2-5 y$ & $5-8 y$ & $>8 \mathrm{y}$ & & M & $\mathrm{F}$ & \\
\hline \multirow{6}{*}{$\begin{array}{l}\chi^{2}=57.346 \\
P<0.0001\end{array}$} & $\begin{array}{c}7 \\
(7.45 \%)\end{array}$ & $3(3.19 \%)$ & $\begin{array}{c}1 \\
(1.06 \%)\end{array}$ & 0 & $\begin{array}{c}\chi^{2}=1.5277 \\
P=0.46586\end{array}$ & $5(5.32 \%)$ & $6(6.38 \%)$ & $P=1$ \\
\hline & $\begin{array}{c}2 \\
(3.85 \%)\end{array}$ & 0 & $\begin{array}{c}2 \\
(3.85 \%)\end{array}$ & 0 & $\begin{array}{c}\chi^{2}=5.3909 \\
P=0.14531\end{array}$ & $2(3.85 \%)$ & $2(3.85 \%)$ & $P=1$ \\
\hline & $\begin{array}{c}17 \\
(26.15 \%)\end{array}$ & $\begin{array}{c}9 \\
(13.85 \%)\end{array}$ & $\begin{array}{c}1 \\
(1.54 \%)\end{array}$ & 0 & $\begin{array}{c}\chi^{2}=1.5838 \\
P=0.45298\end{array}$ & $14(21.54 \%)$ & $13(20.00 \%)$ & $P=0.8036$ \\
\hline & $\begin{array}{c}14 \\
(25.45 \%)\end{array}$ & $\begin{array}{c}13 \\
(23.64 \%)\end{array}$ & $\begin{array}{c}1 \\
(1.82 \%)\end{array}$ & $3(5.45 \%)$ & $\begin{array}{c}\chi^{2}=9.573 \\
P=0.022568\end{array}$ & $18(32.73 \%)$ & $13(23.64 \%)$ & $P=0.42237$ \\
\hline & $\begin{array}{c}7 \\
(10.00 \%)\end{array}$ & $5(7.14 \%)$ & 0 & 0 & $\begin{array}{l}\chi^{2}=1.5448 \\
P=0.2139\end{array}$ & $6(8.57 \%)$ & $6(8.57 \%)$ & $P=0.75436$ \\
\hline & $\begin{array}{c}47 \\
(13.99 \%)\end{array}$ & $\begin{array}{c}30 \\
(8.93 \%)\end{array}$ & $\begin{array}{c}5 \\
(1.49 \%)\end{array}$ & $3(0.89 \%)$ & $\begin{array}{l}\chi^{2}=2.3234 \\
P=0.50806\end{array}$ & $45(13.39 \%)$ & $40(11.90 \%)$ & $P=0.209$ \\
\hline
\end{tabular}




\section{DISCUSSION}

In this study the prevalence for D. immitis of $25.30 \%$ was confirmed for Northern part of Serbia. The results gained in this study are important from the veterinary point of view, but also from the Public Health point of view. This study shows persistence of dirofiariosis in shelters under different maintaining conditions. By comparing the data during the last seventeen years, it can be stated that there is a constant increase of prevalence for $D$. immitis antigen in dogs in northern part of Serbia over the years. Retrospectively, in 2003-2004, prevalence for D. immitis in dogs was 5.9-7\% [39], in 2006-2007, prevalence for D. immitis in dogs with clinical symptoms was $80 \%$, but in dogs with no clinical symptoms it was $10-11 \%$ [33]. During the period from 2009 to 2013, prevalence for D. immitis in dogs with or without clinical symptoms was $27.6 \%$ [37]. Pajković et al. [26] reported that the prevalence for D. immitis in military dogs was $14 \%$, in time period from 2004 to 2010. Savić et al. [36] in a study from 2013-2014, showed that the prevalence for D. immitis in hunting and military dogs was $22.78 \%$ and for pet dogs prevalence for D. immitis was found to be $22 \%$. In the same study, the authors have found a lower prevalence for $D$. immitis in dogs from asylum, namely only $3.12 \%$, but in this study only one asylum was analysed. The total prevalence in pet, military and asylum dogs reported by the authors [36] for D. immitis, was $15.29 \%$, and in $92.3 \%$ of positive samples, D. immitis were confirmed by PCR. During the period 2015-2017, Savić et al. [38] analysed 482 dog blood samples from dogs entering the shelters and asylums, and they concluded that the prevalence for $D$. immitis among stray dogs in Vojvodina region is between 5\% and $8 \%$, that more prevalent is $D$. immitis than $D$. repens. In the latest published research in Vojvodina, Potkonjak et al. [29] detected infection with Dirofilaria spp. in $27.1 \%$ of the stray dogs. Dirofilaria spp. infection is widespread in the countries surrounding Serbia also. The prevalence for $D$. immitis in dogs from Hungary was reported to be $8.1 \%$ [6], 3.3\%-7.2\% in Romania [13,21], 7.4\%-9.2\% in Bulgaria [11,15], but Panayotova-Pencheva et al. [27] found adult D. immitis during the necropsies of dogs and reported the prevalence for D. immitis in dogs of $33.3 \%$. The prevalence for $D$. immitis in dogs from North Macedonia was reported to be $12.5 \%$ [16]. Rapti \& Rehbein [30] reported the prevalence for heartworm in dogs from
Albania as $13.5 \%$. The prevalence for $D$. immitis in dogs from Bosnia and Herzegovina was reported to be $3.1 \%$ [43], and $0.6 \%-7.5 \%$ in Croatia $[12,14]$.

The prevalence found in this study for the Northern part of Serbia is rather high compared to the neighboring countries. It is also higher than in the Southern part of the country. One example is the wider area of Leskovac city where the prevalence of D. immitis is $8.51 \%$ [19]. This could also be due to the fact that much more research has been done in dogs and wild canids in the Northern part of Serbia, but it also is because of the different landscape. The South of the country is more hilly and not as humid as the Northern part. It is also interesting that South Bačka region has a total prevalence for D. immitis of $27.44 \%$ and the Middle Banat region has a lower prevalence of $17.14 \%$. This could be due to the fact that less samples were analysed from the Middle Banat region, but it can be also a consequence of the geographic factors. In 2 dogs from ayzlum B microfilariae of $D$. immitis were not detected, even though they were positive by ELISA. After analyzing the results it was found out that those dogs were actually treated with a larvicidae therapy for one time before the sampling. So, those two dogs were positive, since they were not yet cured from the adult forms of Dirofilaria. These dogs were treated with a "slow kill" therapy which is based on elimination of larval stages and adults remain live for some time [20]. The possibility of occult infection is about $20 \%$ in dogs and it means infection with adult Dirofilaria immitis in the absence of circulating microfilariae. It can be detected in dogs with prepatent infection, unisexual heartworm infection, drug-induced sterility of adult heartworms, and an immune-mediated infection [31]. In our case it was a consequence of drug treatment.

In all the shelters there is a significant diference between the prevalence for $D$. immitis in dogs under 2 years of age, compared to all the other age groups. This was expected even though it is more possible that older dogs have adult forms of $D$. immitis. There are two reasons for this situation that especially refers to shelters. The first one is that there are a lot more young dogs in the shelters than the old ones (over $60 \%$ were dogs under 2 years of age in all the shelters except in shelter B). For that reason there were more young dogs available for sampling then the older ones. The other reason is that in some shelters (B and partly D) when dogs enter the shelter they are checked for $D$. immitis 
infection and if positive, they are in most cases treated with larvicide therapy for some time [20].

In relation to the sex of dogs which were analysed, approximately half were males and half were females in every shelter. There was no significant difference between males and females in any of the shelters, meaning that the prevalence for $D$. immitis was similar for both sexes in all of the shelters. There is no evidence in the literature that sex of dog influences in any way the infection with Dirofilaria immitis.

\section{CONCLUSIONS}

The results of this study indicate the persistence of Dirofilaria immitis infection in dogs from 5 shelters. The shelters are placed in South Bačka and Central Banat districts, in Autonomous Province of Vojvodina, Northern part of Serbia. The study was done during the period from May 2017 to October 2019. These results indicate that dirofiariosis should always be considered in this region, which is endemic for the disease during the past years. This also means that shelters can serve as sentinels of $D$. immitis infection. They can be reservoirs for the disease in dogs but also in humans. Dogs from shelters rarely have preventive methods applied against $D$. immitis infection and in most cases they are without any protection against vector-borne diseases. Due to public health threats, it is necessary to enable routine diagnostic testing for dogs in shelters and treatment of infected animals, as well as prophylactic treatment of healthy dogs to reduce the spread of infection to other dogs and humans.

\section{MANUFACTURERS \\ ${ }^{1}$ Nova Tec Immundiagnostica. Dietzenbach, Germany \\ ${ }^{2} \varnothing$ yvind Hammer, Natural History Museum, University of Oslo. Oslo, Norway.}

Declaration of interest. The authors report no conflict of interest. The authors alone are responsible for the content and writing of the manuscript.

\section{REFERENCES}

1 Avellis F.O., Kramer L.H., Mora P., Bartolino A., Benedetti P. \& Rivasi F. 2011. A case of human conjunctival dirofilariosis by Dirofilaria immitis in Italy. Vector-Borne and Zoonotic Diseases. 11(4): 451-452. DOI: 10.1089/ vbz.2010.0067.

2 Bazzocchi C., Mortarino M., Grandi G., Kramer L.H., Genchi C., Bandi C., Genchi M., Sacchi L. \& McCall J.W. 2008. Combined ivermectin and doxycycline treatment has microfi laricidal and adulticidal activity against Dirofilaria immitis in experimentally infected dogs. International Journal of Parasitology. 38(12): 1401-1410. DOI: 10.1016/j. ijpara.2008.03.002.

3 Capelli G., Genchi C., Baneth G., Bourdeau P., Brianti E., Cardoso L., Danesi P., Fuehrer H.P., Giannelli A., Ionica A.M., Maia C., Modry D., Montarsi F., Krücken J., Papadopoulos E., Petrić D., Pfeffer M., Savić S., Otranto D., Poppert S. \& Silaghi C. 2018. Recent advances on Dirofilaria repens in dogs and humans in Europe. Parasites \& Vectors. 11(1): 663. DOI: 10.1186/s13071-018-3205-x.

4 Dean A.G., Sullivan K.M. \& Soe M.M. OpenEpi: Open Source Epidemiologic Statistic for Public Health. Version. www.OpenEpi.com, update 2013/04/06.

5 Dimitrijević S. 1999. Dirofilariosis ante portas - Dirofilarioza ante portas. In: Proceedings of First Congress of Clinica Veterinaria 1. Proceedings. (Serbia).p.58.

6 Farkas R., Mag V., Gyurkovszky M., Takács N., Vörös K. \& Solymosi N. 2020. The current situation of canine dirofilariosis in Hungary. Parasitology Research. 119: 129-135. DOI: 10.1007/s00436-019-06478-5.

7 Genchi C. 2012. State of art of dirofilarial infections in Europe. Proceedings of the 3rd European Dirofilaria days (Parma, Italy). pp.14-16.

8 Genchi G., Bowman D. \& Drake J. 2014. Canine heartworm disease (Dirofilaria immitis) in Western Europe: survey of veterinary awareness and perceptions. Parasites \& Vectors. 7: 206-213. DOI: 10.1186/1756-3305-7-206.

9 Genchi G., Kramer L.H. \& Rivasi F. 2011. Dirofilarial Infections in Europe. Vector-Borne and Zoonotic Diseases. 11(10): 1307-1317. DOI: 10.1089/vbz.2010.0247.

10 Genchi G., Venco L. \& Genchi M. 2007. Guideline for the laboratory diagnosis of canine and feline Dirofilaria infections. In: Mappe Parassitologiche 8, Dirofilaria. Chap.11. (Naples, Italy). pp.137-145.

11 Georgieva D., Kirkova Z. \& Ivanov A. 2001. A study on the prevalence and diagnostics of dirofilariosis (heartworm disease) in carnivores. Bulgarian Journal of Veterinary Medicine. 4: 231-236. 
12 Holler D., Racz A., Bošnir J. \& Petrak O. 2010. The prevalence of dirofilariosis in the hinterland of the Istrian peninsula. Medica Jadertina. 40(3-4): 67-74.

13 Ionică A.M., Matei I.A., Miceran V., Dumitrache M. O., D’Amico G., Györke A., Panchev N., Annoscia G., Albrechová K., Otranto D., Modrý D. \& Michalca A.D. 2014. Current survey on the prevalence and distribution of Dirofilaria spp. and Acanthocheilonema reconditum infections in dogs in Romania. Parasitology Research. 114: 975982. DOI: $10.1007 / \mathrm{s} 00436-014-4263-4$.

14 Jurković D., Becek A, Huber D., Mihaljević Ž., Polkinghorne A., Martinković F., Lukačević D., Pilat M., Brezak R., Bosnić S. \& Beck R. 2018. Seroprevalence of vector-borne pathogens in dogs from Croatia. Parasitology Research. 118: 347-352. DOI: $10.1007 / \mathrm{s} 00436-018-6129-7$

15 Kirkova Z., Ivanova A. \& Georgieva A. 2007. Dirofilariosis in dogs and wild carnivores in Bulgaria. In: Dirofilaria immitis and D. repes in Dog and Cat and Human Infections; Abstracts of the First European Dirofilaria Days. (Naples, Italy). p.204.

16 Kochevski Z., Atanskova E., Nikolovski G. \& Stefanovska J. 2010. Presence of filariasis in police dogs in the region of Skopje. In: Days of Veterinary Medicine (Ohrid, North Macedonia). p.10.

17 Kramer L., Crosara S., Gnudi G., Genchi M., Viglietti A. \& Quintavalla C. 2018. Wolbachia, doxycycline and macrocyclic lactones: New prospects in the treatment of canine heartworm disease. Veterinary Parasitology. 254: 9597. DOI: 10.1016/j.vetpar.2018.03.005.

18 Krstić M., Gabrielli S., Ignjatović M., Savić S., Cancrini G., Ranđelović G., Momčilović S., Stanojev S. \& Otašević S. 2017. An appraisal of canine and human cases reveals an endemic status of dirofilariosis in parts of Serbia. Molecular and Cellular Probes. 31: 37-41. DOI: 10.1016/j.mcp.2016.08.005.

19 Manić M., Prokić N., Gojković K., Đorić G., Vasić A., Marić J., Vojinović D. \& Đuričić B. 2014. Seroprevalence of some infectious diseases in stray dogs in the wider territory of Leskovac city. Archives of Veterinary Medicine. 7(1): 19-27. DOI: 10.46784/e-avm.v7i1.121.

20 McCall J.W., Kramer L., Genchi C., Guerrero J., Dzimanski M.T., Mansour A., McCall S.D. \& Carson B. 2014. Effects of Doxycycline on Heartworm Embryogenesis, Transmission, Circulating Microfilaria, and Adult Worms in Microfilaremic Dogs. Veterinary Parasitology. 206(1-2): 5-13. DOI: 10.1016/j.vetpar.2014.09.023.

21 Miceran V., Dumitrache M.O., Györke A., Pantchev N., Jodies R., Michalca A.D. \& Cozma V. 2012. Seroprevalence and geographic distribution of Dirofilaria immitis and tick-borne infections (Anaplasma phagocytophilum, Borrelia burgdorferi sensu lato, and Ehrlichia canis) in dogs from Romania. Vector-Borne Zoonotic Diseases. 12(7): 595-604. DOI: 10.1089/vbz.2011.0915.

22 Milosavljević P. \& Kulišić Z. 1989. The first cases of dirofilariasis in dogs Yugoslavia. Veterinarski Glasnik. 43(1): 71-76.

23 Morchón R., Carretón E., Gómez P.J., Diosdado A. \& González-Miguel J. 2016. Heartworm disease vectors in Europe - new distribution trends. Parasites \& Vectors. 10(Suppl 1): A22. DOI: 10.3389/fphys.2012.00196.

24 Morchón R., Carretón E., González-Miguel J. \& Mellado-Hernández I. 2012. Heartworm disease (Dirofilaria immitis) and their vectors in Europe - new distribution trends. Frontiers in Physiology. 3(196). DOI: 10.3389/fphys.2012.00196

25 Moorhead A. 2020. Dirofilaria immitis. Infection Disase Manual Infectious Diseases of Concern to Captive and Free Ranging Wildlife in North America. Publication of American Association of Zoo Veterinarians Animal Health and Welfare Committee. (Wilmingon, USA). pp.192-194

26 Pajković D., Savić S., Veljković P. \& Grgić Ž. 2010. Study on dirofilariosis in military dogs within the army of Serbia. Archives of Veterinary Medicine. 3(2): 53-58. DOI: 10.46784/e-avm.v3i2.203.

27 Panayotova-Pencheva M.S., Mirchev R.L. \& Trifonova A.P. 2016. Dirofilaria immitis infection in carnivores from Bulgaria: 2012-2013 Update. Bulgarian Journal of Veterinary Medicine. 19(2): 153-162. DOI: 10. 15547,\&ivm.

28 Panić V., Bekvalac R., Fenjac I., Potkonjak A., Otašević S. \& Savić S. 2016. Diagnostics and therapy of Dirofilaria immitis infections in an isolated dog shelter. Parasites \& Vectors. 10(Suppl 1): A24.

29 Potkonjak A., Rojas A., Gutiérrez R., Nachum-Biala Y., Kleinerman G., Savić S., Polaček V., Pušić I., Harrus S. \& Baneth G. 2020. Molecular survey of Dirofilaria species in stray dogs, red foxes and golden jackals from Vojvodina, Serbia. Comparative Immunology, Microbiology and Infectious Diseases. 68. DOI: 10.1016/j.cimid.2019.101409

30 Rapti R. \& Rehbein S. 2010. Seroprevalence of canine heartworm (Dirofilaria immitis) infection in Albania. Parasitology Research. 107: 481-485. DOI: 10.1007/s00436-010-1914-y. 
31 Rawlings C.A. 1986. Heartworm Disease in Dogs and Cats. Philadelphia: Saunders, pp.104-114.

32 Savić S., Ćurčin Lj., Žekić-Stošić M., Marčić D., Odalović M., Petej Z., Ćurčić V. \& Potkonjak A. 2019. Interpretation and comparison of available diagnostic methods for canine dirofilariosis. Abstracts book. XXI Symposium of Epizootiologists and Epidemiologists / XXI Epizootiological Days (Novi Sad, Serbia). pp.182-183.

33 Savić S., Grgić Ž., Vujkov B., Fenjac I., Pajković D. \& Žekić M. 2009. Determination of canine dirofilariasis by ELISA method and modified Knott's test. Archives of Veterinary Medicine. 2(2): 71-77.

34 Savic S., Potkonjak A., Stosic-Zekic M. \& Petrovic T. 2019. The emergence of vector-borne diseases in new locations. In: Roig B., Weiss K. \& Thireau V. (Eds) Management of Emerging Public Health Issues and Risks Multidisciplinary Appraches to the Changing Environment. Chap. 4. Elseveir, pp. 89-99. DOI: 10.1016/B978-0-12-813290-6.00004-4

35 Savić S., Vidić B., Grgić Ž., Jurišić A., Ćurčić V., Ružić M. \& Lolić Z. 2012. Canine vector-borne zoonosis in Vojvodina. Archives of Veterinary Medicine. 5(1): 77-87. DOI: 10.46784/e-avm.v5i1.164.

36 Savic S., Vidic B., Grgic Z., Petrovic T., Potkonjak A., Cupina A., Vaselek S. \& Petric D. 2015. Dirofilariosis and Leishmaniasis in the Northern Region of Serbia. Intech. Chap.6. pp. 108-125. DOI: 10.5772/61761

37 Savić S., Vidić B., Grgić Ž., Potkonjak A. \& Spasojević Kosić Lj. 2014. Emerging vector-borne diseases - incidence through vectors. Frontiers in Public Health. DOI: 10.3389/fpubh.2014.00267

38 Savić S., Žekić-Stošić M., Marčić D., Potkonjak A., Ćurčin Lj., Milojković N., Ružić M. \& Otašević S. 2018. Dirofilariosis - Disease status in Serbia - Reservoars and risk for public health. Abstracts book. XX Symposium of Epizootiologists and Epidemiologists / XX Epizootiological Days. (Vrnjačka Banja, Serbia). pp.170-171.

39 Savić-Jevđenić S., Vidić B., Grgić Ž. \& Milovanović A. 2004. Fast diagnostic of dirofilariosis in Novi Sad region. Veterinarski glasnik. 58(5-6): 693-698.

40 Spasojević Kosić Lj., Lalošević V., Lalošević D, Simin S., Vasić I. \& Kuruca Lj. 2012. Prevalence of dirofilariosis in pet dogs in Novi Sad. Contemporary Agriculture. 61(3-4): 247-254.

41 Spasojević Kosić Lj., Lalošević V., Simin S. \& Kuruca Lj. 2016. Dirofilariosis and angiostrongilosis in pet and hunting dogs in Novi Sad, Vojvodina, Serbia. Archives of Veterinary Medicine. 9(2): 53-61. DOI: 10.46784/e-avm.v9i2.89.

42 Tasić A., Rossi L., Tasić S., Miladinović-Tasić N., Ilić T. \& Dimitrijević S. 2008. Survey of canine dirofilariosis in Vojvodina, Serbia. Parasitology Research. 103(6): 1297-1302. DOI: 10.1007/s00436-008-1132-z.

43 Zahirović A., Omeragić J., Jažić A. \& Rukavina D. 2015. The occurrence and geographical distribution of canine dirofilariasis in Bosnia \& Herzegovina. Conference: Second Conference on Negleted Vectors and Vector-borne Diseases (EURNEGVEC) with Management Committee and working group meetings of COST Action TD1303 (Izmir, Turkey). Poster presentation. 